\title{
Die Rethtzgnumbjäke
}

Des

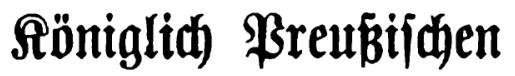

\section{Dhervermaltunģgeridgts.}

Begründet von $\Re$. $\mathfrak{B a r e \mathfrak { y }}$.

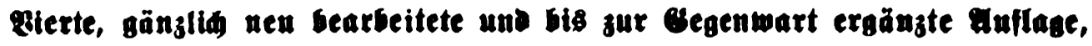

heraußgegeben bon

\section{Fr. Aunze,}

toeil. Bairll. (Selheimer Dberregierungšrnt, und

\author{
Dr. (3. Aaub,
}

Wirtlider Beheimer Sberregierungarat.

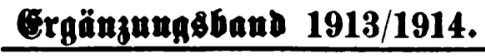

\section{Bearbeitet von}

\section{Dr. (5. Aank,}

Präjibent bes saijerl. Sanalamţ in sitel,

Wirtlițer (Seheimer Eberregicrungżat.

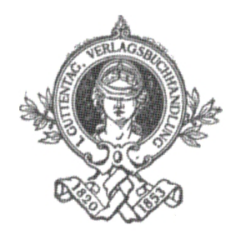

Berlin 1915.

3. Guttentag, Berlagşนuhhaudiung,

(5. m. b. $\mathfrak{b}$. 
